US Army Corps

of Engineers ${ }_{\circledast}$

Engineer Research and

Development Center

Aquatic Plant Control Research Program

\title{
Efficacy of Florpyrauxifen-benzyl on Dioecious Hydrilla and Hybrid Water Milfoil - Concentration and Exposure Time Requirements
}

Christopher R. Mudge, Bradley T. Sartain, Kurt D. Getsinger, and Michael. D. Netherland 
The US Army Engineer Research and Development Center (ERDC) solves the nation's toughest engineering and environmental challenges. ERDC develops innovative solutions in civil and military engineering, geospatial sciences, water resources, and environmental sciences for the Army, the Department of Defense, civilian agencies, and our nation's public good. Find out more at www.erdc.usace.army.mil.

To search for other technical reports published by ERDC, visit the ERDC online library at https://erdclibrary.on.worldcat.org/discovery. 
Efficacy of Florpyrauxifen-benzyl on Dioecious Hydrilla and Hybrid Water Milfoil - Concentration and Exposure Time Requirements

\author{
Christopher R. Mudge \\ US Army Engineer Research and Development Center \\ Environmental Laboratory \\ Louisiana State University \\ 108 MB Sturgis Hall \\ Baton Rouge, Louisiana 70803 \\ Bradley T. Sartain and Kurt D. Getsinger \\ US Army Engineer Research and Development Center \\ Environmental Laboratory \\ 3909 Halls Ferry Road \\ Vicksburg, MS 39180-6199 \\ Michael D. Netherland (deceased) \\ US Army Engineer Research and Development Center \\ Environmental Laboratory \\ University of Florida \\ 7922 NW 71st St. \\ Gainesville, FL 32653
}

Final Report

Approved for public release; distribution unlimited.

Prepared for Headquarters, US Army Corps of Engineers

Washington, DC 20314-1000

Under Funding Account Code U4359660; AMSCO Code 075098 


\section{Abstract}

This study conducted small-scale trials under various concentration and exposure time (CET) scenarios to determine florpyrauxifen-benzyl activity on dioecious hydrilla and hybrid watermilfoil and determine impact on water stargrass and elodea. Hydrilla treated with 12,24 , or $36 \mu$ gactive ingredient (a.i.) $\mathrm{L}^{-1}$ florpyrauxifen-benzyl and exposed for 12, 24, or $48 \mathrm{hr}$ under outdoor mesocosm conditions was reduced in biomass by $30-75 \%$ at 8 weeks after treatment (WAT). An additional hydrilla trial at the same herbicide concentrations, but under longer exposures $(24,72$, or $168 \mathrm{hr}$ ), resulted in $33-85 \%$ plant control. Under indoor conditions, hybrid watermilfoil dry weight decreased $98-100 \%$ with subsurface applications

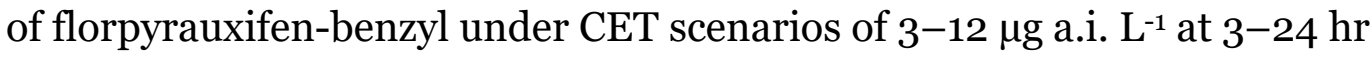
exposure times in a growth chamber trial. Under shorter exposure periods (0.5-4 hr) in a follow-up trial, low doses (3-9 $\mu$ g a.i. $\left.\mathrm{L}^{-1}\right)$ achieved 50$100 \%$ control of hybrid watermilfoil. In the same trial, the nontarget species water stargrass and elodea proved relatively tolerant to the florpyrauxifen-benzyl at doses up to $6 \mu \mathrm{g}$ a.i. $\mathrm{L}^{-1}(4 \mathrm{hr}$ exposure) and $9 \mu \mathrm{g}$ a.i. $\mathrm{L}^{-1}$ ( $1 \mathrm{hr}$ exposure). These small-scale trials demonstrate florpyrauxifen-benzyl's potential to selectively manage invasive species.

DISCLAIMER: The contents of this report are not to be used for advertising, publication, or promotional purposes. Citation of trade names does not constitute an official endorsement or approval of the use of such commercial products. All product names and trademarks cited are the property of their respective owners. The findings of this report are not to be construed as an official Department of the Army position unless so designated by other authorized documents. 


\section{Contents}

Abstract............................................................................................................................... if

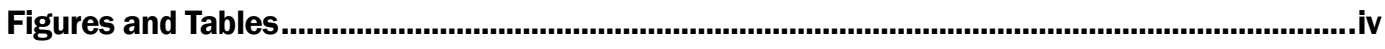

Preface

1 Introduction.............................................................................................................................. 1

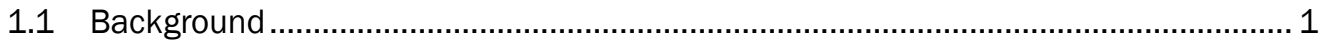

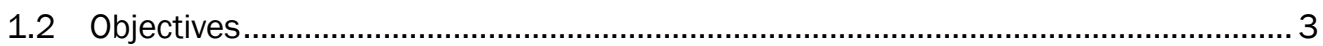

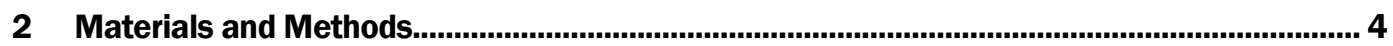

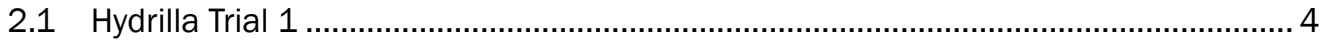

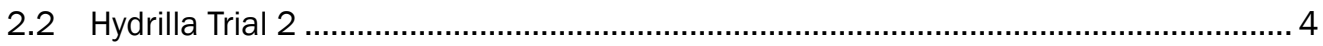

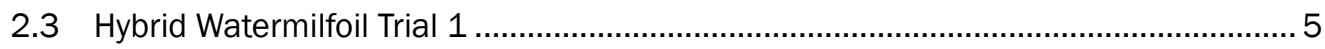

2.4 Hybrid Watermilfoil and Nontarget Species Trial ................................................... 6

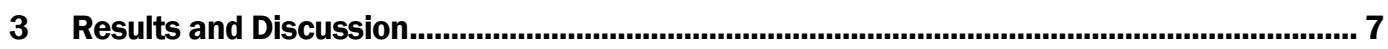

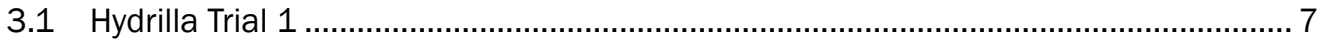

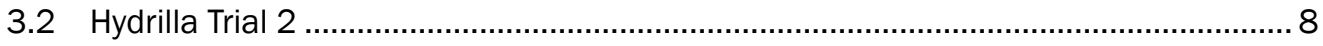

3.3 Hybrid Watermilfoil Trial 1 ................................................................................. 9

3.4 Hybrid Watermilfoil and Non-Target Species Trial .................................................. 10

4 Conclusions..................................................................................................................13

References.......................................................................................................................................14

Acronyms and Abbreviations ....................................................................................................14

\section{Report Documentation Page}




\section{Figures and Tables}

\section{Figures}

Figure 1. Mean dry weight ( $g \pm S E$ ) response of hydrilla 8 weeks after treatment (WAT) with subsurface applications of florpyrauxifen-benzyl in an outdoor mesocosm setting. Numbers behind herbicide concentrations ( $\mu \mathrm{g}$ active ingredient [a.i.] L-1) represent exposure time (hr). Horizontal line represents pretreatment biomass. Treatments with the same letter are not significant according to Fisher's Protected LSD $(\alpha=0.05, n=4)$.

Figure 2. Mean dry weight ( $g \pm \mathrm{SE}$ ) response of hydrilla 8 WAT with subsurface applications of florpyrauxifen-benzyl in an outdoor mesocosm setting. Numbers behind herbicide concentrations ( $\mu$ g a.i. $\mathrm{L}^{-1}$ ) represent exposure time (hr). Horizontal line represents pretreatment biomass. Treatments with the same letter are not significant according to Fisher's Protected $\operatorname{LSD}(\alpha=0.05, n=4)$. 9

Figure 3. Mean dry weight $(g \pm S E)$ response of hybrid watermilfoil 8 WAT with subsurface applications of florpyrauxifen-benzyl in an outdoor mesocosm setting. Numbers behind herbicide concentrations ( $\mu$ g a.i. $\left.L^{-1}\right)$ represent exposure time (hr). Horizontal line represents pretreatment biomass. Treatments with the same letter are not significant according to Fisher's Protected LSD $(\alpha=0.05, n=4)$ 10

\section{Tables}

Table 1. Mean dry weight ( $g \pm S E$ ) response of hybrid watermilfoil, elodea, and water stargrass 8 WAT with subsurface applications of florpyrauxifen-benzyl in a growth chamber setting. 


\section{Preface}

This research was conducted for the Aquatic Plant Control Research Program (APRCP) under Funding Account Code U4359660 and AMSCO Code 075098 and funding assistance was provided by the Florida Fish and Wildlife Conservation Commission Invasive Plant Management Section and USACE Jacksonville District (SAJ). The APCRP is sponsored by Headquarters, US Army Corps of Engineers (HQUSACE), and is assigned to the US Army Engineer Research and Development Center (ERDC) under the purview of the Environmental Laboratory (EL), Vicksburg, Mississippi. Funding for the APCRP was provided under the Department of the Army Appropriation Number 96x3122, Construction General. The APCRP program manager is Mr. Michael Greer.

The work was performed by the Aquatic Ecology and Invasive Species Branch (EEA) of the Ecosystem Evaluation and Engineering Division (EE), US Army Engineer Research and Development Center, Environmental Laboratory (ERDC-EL). At the time of publication, Mr. Alan Katzenmyer was Chief, EEA; Mr. Mark D. Farr was Chief, EE; Dr. Christine M. VanZomeren was Acting Associate Technical Director for Civil Works Environmental Engineering and Sciences; and Dr. Jennifer Seiter-Moser was the Technical Director for the Civil Works Environmental Engineering and Sciences Office. The Deputy Director of ERDC-EL was Dr. Jack E. Davis and the Director was Dr. Edmond J. Russo.

Appreciation is extended to Trista Galivan, Nick Firmin, Jan Freedman, William Prevost, Jens Beets, Chetta Owens, and Dr. Mark Heilman for technical assistance throughout this research.

COL Teresa A. Schlosser was Commander of ERDC, and Dr. David W. Pittman was the Director.

Portions of the methods section of this report have been edited and reprinted with permission from Christopher R. Mudge, Kurt D. Getsinger, and Cody J. Gray. 2015.

"Endothall (Dimethylalkylamine) Concentration Exposure Time Evaluation Against Two Populations of Elodea canadensis." Journal of Aquatic Plant Management 53, no. 1 (January): 130-3. http://www.apms.org/wp/wp-content/uploads /japm-53-01-130.pdf. No rights reserved. 


\section{Introduction}

\subsection{Background}

In the United States, aquatic herbicides are one of the most commonly used tools to manage problematic aquatic plants (Netherland 2014). As nuisance aquatic vegetation continues to spread, new herbicides, herbicide control techniques, and use patterns are evaluated and developed through research and field demonstrations by government, university, and industry scientists. Prior to 2018, the US Environmental Protection Agency (USEPA) registered 14 herbicides, with 6 known and 2 unknown modes of action for aquatic use (Netherland and Jones 2012; University of Florida 2018). Although six herbicides were registered for aquatic sites during the past decade (bispyribac-sodium, carfentrazone-ethyl, imazamox, flumioxazin, topramezone, and penoxsulam) (Netherland 2014; University of Florida 2018), the complexity of the aquatic environment and desire for species selectivity warrants additional tools-especially those with different modes of action to mitigate overuse of products and potential resistance and tolerance issues in the future.

The submersed aquatic freshwater angiosperm hydrilla (Hydrilla verticillata L.f. Royle) originated in Asia or Africa and has become a serious weed problem in the United States and throughout the world (Cook 1985; Haller and Sutton 1975; USDA 2019; Van and Vandiver 1992). Hydrilla quickly outcompetes and replaces native species by forming a surface canopy that reduces light penetration (Haller and Sutton 1975). Langeland (1996) described hydrilla as "the perfect aquatic weed" because of its specialized growth habit, physiological characteristics, and various means of asexual reproduction (293).

Over the past few years, the invasive Eurasian watermilfoil (Myriophyllum spicatum L.) and the native northern watermilfoil (M. sibiricum Komarov) have hybridized in the Great Lakes (Moody and Les 2002, 2007) and Pacific Northwest regions (Moody and Les 2007), which has caused concern for resource agencies. Similar to hydrilla and Eurasian watermilfoil, the hybrid watermilfoil (Myriophyllum spicatum $\times M$. sibiricum) species negatively alters aquatic systems (Berger, Netherland, and MacDonald 2015). In addition, these hybrid populations show less sensitivity to aquatic herbicides traditionally used in management 
programs, such as 2,4-D, triclopyr, fluridone, and topramezone, that previously proved very effective at controlling Eurasian watermilfoil (Glomski and Netherland 2010; Berger, Netherland, and MacDonald 2012; Thum et al. 2012; LaRue et a. 2013; Berger, Netherland, and MacDonald 2015).

In 2018, the arylpicolinate herbicide florpyrauxifen-benzyl-4-amino-3chloro-6-(4-chloro-2-fluoro-3-methoxyphenyl)-5-fluoro-pyridine-2-benzyl ester-received aquatic registration in the United States (University of Florida 2018). Prior to its evaluation for aquatic use, this herbicide was granted a label (Loyant, Corteva) for use in rice (Weimer et al. 2015; Netherland and Richardson 2016; Dow AgroSciences 2017). Results to date suggest florpyrauxifen-benzyl has several unique properties that may allow natural resource managers to develop new strategies for selective invasive plant control. Growth chamber, mesocosm, and greenhouse research was conducted to determine baseline data for florpyrauxifenbenzyl activity on crested floating heart (Nymphoides cristata [Roxb.] Kuntze); dioecious hydrilla; Eurasian watermilfoil; elodea (Elodea canadensis Michx.); megalodonta (Bidens beckii Torr. Ex Spreng) (Netherland and Richardson 2016); alligatorweed (Alternanthera philoxeroides [Mart.] Griseb.); fanwort (Cabomba caroliniana Gray); monoecious hydrilla; and parrotfeather (Myriophyllum aquaticum [Vell.] Verdc.) (Richardson, Haug, and Netherland 2016). Netherland and Richardson (2016) evaluated static (14- or 28-day) in-water concentrations of florpyrauxifen-benzyl between 0.01 and $243 \mu g^{1}$ active ingredient (a.i.) $\mathrm{L}^{-1}$ and found most plants to be highly susceptible to the herbicide with $\mathrm{EC}_{50}$ (effective concentration to reduce biomass by $50 \%$ ) values ranging 0.1-23.9 $\mu \mathrm{g}$ a.i. $\mathrm{L}^{-1}$. Conversely, Richardson, Haug, and Netherland (2016) determined EC50 values were $<1 \mu \mathrm{g}$ a.i. $\mathrm{L}^{-1}$ for most target plants when exposed for 4 weeks.

This unique molecule is especially beneficial since the previously registered synthetic auxin herbicides, that is, 2,4-D and triclopyr, do not have activity on the monocot hydrilla at allowable use rates (Enloe et al. 2018). This new active ingredient provides different capabilities and an alternative means and mode of action to manage this submersed species. Also, previous

1. For a full list of the spelled-out forms of the units of measure used in this document, please refer to US Government Publishing Office Style Manual, 31st ed. (Washington, DC: US Government Publishing Office, 2016), 248-52, https://www.govinfo.gov/content/pkg/GPO-STYLEMANUAL-2016/pdf/GPO-

STYLEMANUAL-2016.pdf. 
mesocosm research (Beets and Netherland 2018) suggests that florpyrauxifen-benzyl has short-term contact time requirements (24 to $72 \mathrm{hr}$ ) for controlling Eurasian watermilfoil, hybrid watermilfoil, and hydrilla as the contact herbicide endothall (Getsinger and Netherland 1997; Netherland, Green, and Getsinger 1991). Beets, Heilman, and Netherland (2019) also investigated the impacts of florpyrauxifen-benzyl at 3, 9, and $27 \mu \mathrm{g}$ a.i. $\mathrm{L}^{-1}$ for 6 or $24 \mathrm{hr}$ exposures as well as static exposures against hybrid watermilfoil, Eurasian watermilfoil, and several native submersed species. The invasive milfoil species were controlled by most concentration and exposure time (CET) treatments, while the native species were less sensitive to florpyrauxifen-benzyl under these same CET conditions.

Although previous research has provided insight into general control and selectivity, follow-up replicated research is required to better understand proper use of florpyrauxifen-benzyl since operational use has recently been initiated. Because the registrant chose not to apply for a USEPA experimental use permit (EUP) (Dr. Mark Heilman, SePRO Corporation, pers. comm., 2018), which permits field application prior to herbicide receiving a pesticide label, additional mesocosm, growth chamber, and greenhouse research to refine use patterns is warranted. In addition, florpyrauxifen-benzyl should be investigated at low concentrations and shorter exposure periods to determine if hybrid watermilfoil will be controlled in waterbodies where high water exchange is an issue. The trials reported in this report represent part of a coordinated, multiscale US Army Engineer Research and Development Center (ERDC), academia, and industry program, conducted in growth chambers and outdoor mesocosms (2016-2019), to create a robust florpyrauxifen-benzyl CET database. This database provides expedited operational guidance for managing the invasive milfoils and hydrilla in public water bodies to support field trials initiated in the United States in 2018.

\subsection{Objectives}

This study sought to evaluate CET requirements of florpyrauxifen-benzyl to control the invasive species hydrilla and hybrid watermilfoil and to determine its impact on the nontarget submersed species elodea and water stargrass (Heteranthera dubia [Jacq.] MacMill) in mesocosm and growth chamber settings. These data will complement and verify results from other studies in the overall program to establish the CET baseline for current understanding of this new herbicide. 


\section{Materials and Methods}

\subsection{Hydrilla Trial 1}

In the summer of 2016, a replicated outdoor mesocosm trial was conducted at the Louisiana State University (LSU) AgCenter Aquaculture Research Facility (AARF) in Baton Rouge, Louisiana, to determine CET requirements for florpyrauxifen-benzyl to control dioecious hydrilla. On 1 June 2016, four healthy sprigs of dioecious hydrilla ( $15 \mathrm{~cm}$ in length) collected from a culture pond at LSU Aquaculture were planted in water-saturated topsoil (Black Cow, Black Gold Compost Company, Oxford, Florida) in 3 L highdensity polyethylene (HDPE) pots that included the slow-release fertilizer Osmocote (19-6-12, The Scotts Company, Marysville, Ohio) at a rate of $2 \mathrm{~g}$ $\mathrm{Kg}^{-1}$ soil. A $2.5 \mathrm{~cm}$ layer of masonry sand was added to the soil surface to assist with particulate matter and nutrient suspension from the soil into the water column to prevent algal contamination. Four pots of hydrilla were placed inside $1136 \mathrm{~L}$ HDPE containers filled with LSU Aquaculture pond water ( $\sim \mathrm{pH} 8.5$ ), maintained with water depths of $46 \mathrm{~cm}$, and plants were acclimatized outdoors under full sunlight.

On 2 August 2016, 9 weeks after planting (WAP), hydrilla were exposed to subsurface applications of florpyrauxifen-benzyl (ProcellaCOR SC, SePRO Corporation, Carmel, Indiana) at concentrations of 12,24 , or $36 \mu \mathrm{g}$ a.i. $\mathrm{L}^{-1}$ for 12,24 , or $48 \mathrm{hr}$. At the conclusion of each exposure period, the plants were relocated into a second set of $1136 \mathrm{~L}$ containers filled with herbicidefree pond water and allowed to recover from herbicide exposure. The treatments were randomly assigned to the tanks and replicated four times. For comparison purposes, a nontreated control (reference) was also included. On 22 September 2016, 8 weeks after treatment (WAT), all viable shoot tissues above the soil surface were harvested, dried to a constant weight in an oven $\left(65^{\circ} \mathrm{C}\right)$, and recorded as dry weight biomass. An ANOVA was utilized to compare means of biomass data and means separated using Fisher's Protected LSD $(p \leq 0.05)$.

\subsection{Hydrilla Trial 2}

A second outdoor mesocosm trial was conducted at LSU AARF in the spring of 2017 to determine the efficacy of extended exposures of florpyrauxifen-benzyl on hydrilla. Hydrilla was established using containers as above. There were two growth stages of hydrilla used in this 
trial: mature and immature. Mature hydrilla was established 10 months prior to trial initiation (1 June 2016) and was mature and hardy at time of herbicide application. Conversely, the immature hydrilla was planted one month prior to herbicide treatment (17 April 2017) and was in a young and tender condition at time of herbicide application. Both mature and immature hydrilla were placed inside the same $1136 \mathrm{~L}$ containers with $46 \mathrm{~cm}$ of pond water on the day the immature hydrilla was planted. Treatments were completely randomized and replicated four times.

On 16 May 2017, florpyrauxifen-benzyl was applied subsurface at 12, 24, or $36 \mu \mathrm{g}$ a.i. $\mathrm{L}^{-1}$, and plants were exposed to the treatments for 24,72 , or $168 \mathrm{hr}$, as well as static exposures. At the conclusion of the exposure periods, the chemically treated water was drained from each container and fresh pond water was flushed three times to eliminate aqueous herbicide residue. In addition, a nontreated control (reference) was included to monitor plant growth in the absence of florpyrauxifen-benzyl. At 8 WAT (10 July 2017), all viable plant tissues (for example, shoots and stems) above the soil surface were collected and dried to a constant weight $\left(65^{\circ} \mathrm{C}\right)$ in an oven and recorded as dry weight biomass. No differences were detected between immature and mature hydrilla dry weight data (two-way ANOVA); therefore, all biomass data were pooled, analyzed as a one-way ANOVA, and treatment means separated using Fisher's Protected LSD $(p \leq 0.05)$.

\subsection{Hybrid Watermilfoil Trial 1}

A trial was conducted in 2017 at ERDC in Vicksburg, Mississippi, to determine CET requirements for controlling hybrid watermilfoil with florpyrauxifen-benzyl with short herbicide exposure times. Similar to previous ERDC research trials, a controlled-environment growth chamber equipped with $55 \mathrm{~L}$ glass aquaria and artificial lighting specifically designed for culturing submersed plants was utilized for this experiment (Netherland, Green, and Getsinger 1991; Mudge and Theel 2011; Netherland and Getsinger 2018). Throughout the experiment, the following conditions were maintained for favorable plant growth: temperature $22^{\circ} \mathrm{C}$, water $\mathrm{pH} 7.5^{-8.0}$, and a $14 \mathrm{hr}: 10 \mathrm{hr}$ (light:dark) photoperiod. On 6 June 2017, shoots from a hybrid watermilfoil population (hybridity confirmed by Dr. Ryan Thum, Montana State University) known to be tolerant to 2,4-D, triclopyr, fluridone, and endothall was collected from Hayden Lake, Indiana, and shipped overnight to ERDC. After arrival on 7 June 2017, four healthy apical meristems ( $15 \mathrm{~cm}$ in length) were transplanted into plastic containers 
(750 mL) filled with topsoil amended with Osmocote fertilizer $\left(2 \mathrm{~g} \mathrm{Kg}^{-1}\right.$ topsoil) and saturated with water. After hybrid watermilfoil was transplanted into the container, silica sand ( $1 \mathrm{~cm}$ layer) was added to the soil surface. Two containers of plants were placed in each aquaria and filled with growth culture solution (Smart and Barko 1985).

At 7 WAP, florpyrauxifen-benzyl was administered subsurface to hybrid watermilfoil at 3,6 , or $9 \mu \mathrm{g}$ a.i. $\mathrm{L}^{-1}$, and plants were exposed to the treatments for $3,6,12$, or $24 \mathrm{hr}$. Similar to the hydrilla trial 2, aquaria were drained and refilled twice with reverse osmosis (RO) water and a third time with fresh growth culture solution (Smart and Barko 1985) at the termination of assigned exposure periods to remove any remaining herbicide in the water column. In addition, nontreated aquaria were included as a treatment to compare plant growth in the absence of herbicide. Treatments were replicated four times and completely randomized. At the conclusion of the experiment (4 WAT), viable shoot tissues were harvested, dried to a constant weight at $65^{\circ} \mathrm{C}$, weighed, and analyzed for dry weight biomass. Biomass data were subjected to an ANOVA, and Fisher's Protected LSD $(p \leq 0.05)$ was used to separate means.

\subsection{Hybrid Watermilfoil and Nontarget Species Trial}

A second growth chamber trial was conducted at ERDC in 2018 to determine efficacy on hybrid watermilfoil and selectivity against native elodea and water stargrass at lower florpyrauxifen-benzyl concentrations and shorter exposure times. Plants were obtained from the following sources: hybrid watermilfoil, Hayden Lake, Indiana (hybridity confirmed by R. Thum); elodea, Mississippi State University Geosystems Research Institute (Gray Turnage); and water stargrass, ERDC cultures. Planting and culture techniques were similar to the 2017 hybrid watermilfoil trial above. One container of each species was placed in each aquarium after planting.

At 4 WAP, florpyrauxifen-benzyl was applied to hybrid watermilfoil, elodea and water stargrass at 3,6 , or $9 \mu \mathrm{g}$ a.i. $\mathrm{L}^{-1}$ with exposure times of $0.5,1,2$ or $4 \mathrm{hr}$. Aquaria were drained and refilled three times with a combination of RO and nutrient-amended water to remove herbicide residue at the conclusion of the assigned exposure periods. Nontreated control (reference) aquaria were included in this research trial. All treatments were replicated four times, and the trial was completely randomized. At 5 WAT, all viable shoot biomass were harvested and subjected to the same post-trial procedures as the other hydrilla and milfoil trials. 


\section{Results and Discussion}

\subsection{Hydrilla Trial 1}

Florpyrauxifen-benzyl treatments resulted in bleaching of the hydrilla apical tips within 3 days after treatment (DAT). At 5-10 DAT, bleached apical tips began to abscise and decay, while the stems twisted and the leaves became irregular in appearance $<7$ DAT. Plants exposed to lower herbicide concentrations and shorter exposure times showed visual signs of recovery approximately 2-4 WAT, while plants exposed to higher concentrations and longer exposures did not show signs of recovery until 6 WAT. Recovery symptoms were evident when previously injured stems and leaves began to grow normally and newly formed shoots emerged at the axillary buds and root crowns. At $8 \mathrm{WAT}$, six of the nine CET treatments resulted in $30-75 \%$ hydrilla control (Figure 1).

Figure 1. Mean dry weight ( $g \pm S E$ ) response of hydrilla 8 weeks after treatment (WAT) with subsurface applications of florpyrauxifen-benzyl in an outdoor mesocosm setting. Numbers behind herbicide concentrations ( $\mu$ g active ingredient [a.i.] $\mathrm{L}^{-1}$ ) represent exposure time (hr). Horizontal line represents pretreatment biomass. Treatments with the same letter are not significant according to Fisher's Protected LSD $(\alpha=0.05, n=4)$.

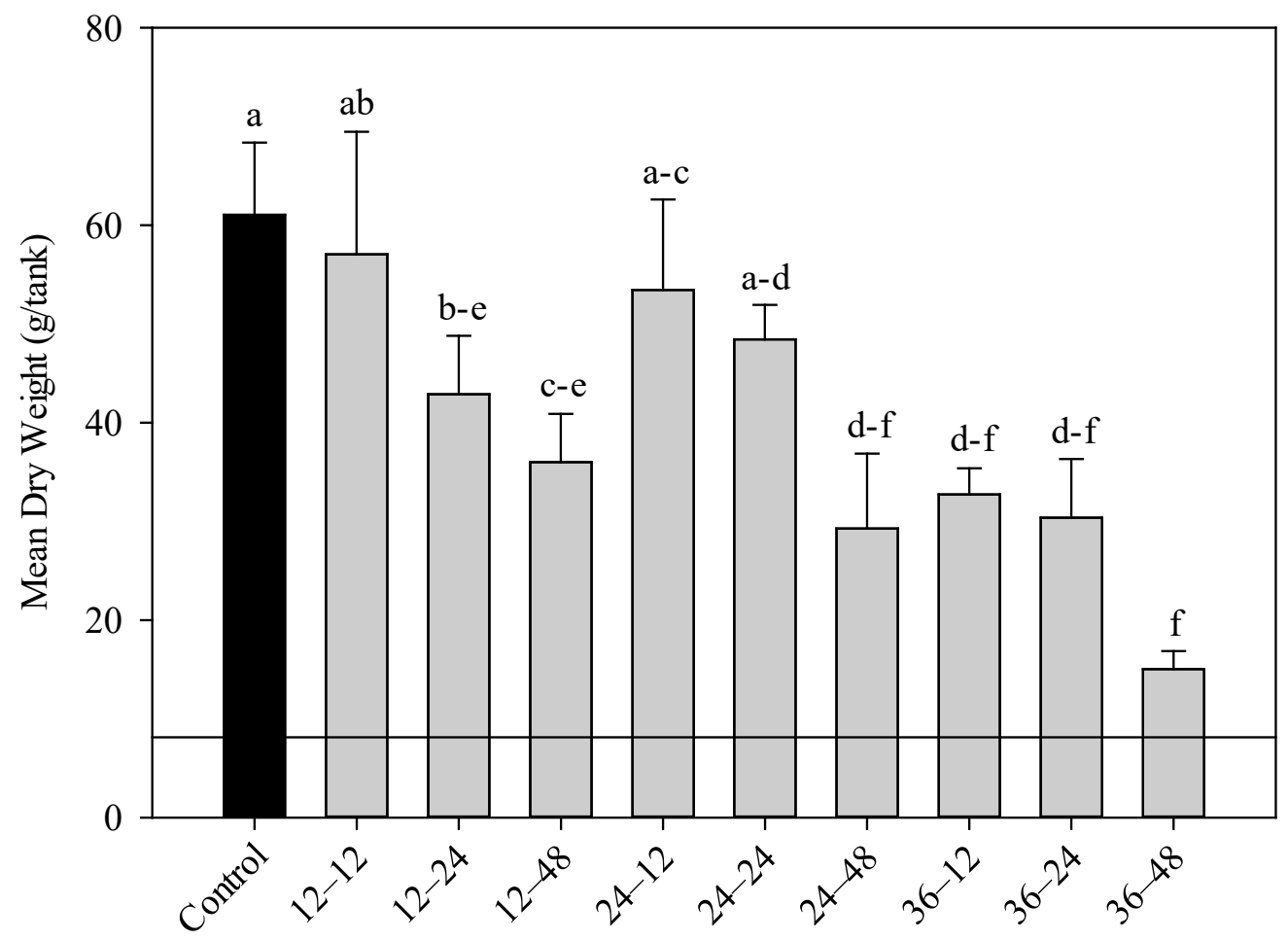

Herbicide Treatments 
These data provide evidence that hydrilla is susceptible to florpyrauxifenbenzyl, but exposures $>36 \mathrm{hr}$ may be required to control this submersed species depending on age of plants and environmental conditions. Beets and Netherland (2018) suggested that water temperature or $\mathrm{pH}$ or both may impact florpyrauxifen-benzyl efficacy. Summer conditions for this tank study included water temperatures $\geq 30^{\circ} \mathrm{C}$ and a $\mathrm{pH}$ range of 7.5-8.0 at treatment that may have influenced short-exposure efficacy, since florpyrauxifen-benzyl efficacy and degradation may be influenced by higher water temperatures and $\mathrm{pH}$ at the time of treatment (Beets and Netherland 2018). On the basis of these findings, factors including herbicide concentration, application timing, and plant maturity may impact efficacy of this herbicide. Future research should investigate the impact of environmental factors and plant age on florpyrauxifen-benzyl efficacy.

\subsection{Hydrilla Trial 2}

Since hydrilla recovered from all treatments in the first trial, exposure time of florpyrauxifen-benzyl was increased in the follow-up trial. The injury symptoms observed on hydrilla in trial 2, under longer exposure times, were similar to those under short exposures of florpyrauxifenbenzyl in trial 1. In general, regardless of plant age (1 month versus 10 months), as herbicide CET increased, hydrilla control increased. Eleven of the twelve florpyrauxifen-benzyl treatments reduced hydrilla biomass by $33-85 \%$ (Figure 2).

Florpyrauxifen-benzyl applied at the lowest concentration of $12 \mu \mathrm{g}$ a.i. $\mathrm{L}^{-1}$ (24 hr exposure) was the only treatment that did not significantly reduce hydrilla biomass in comparison to the nontreated during hydrilla trial 2. If hydrilla is targeted with this dose, exposure periods $>72 \mathrm{hr}$ may needed to achieve adequate control with this herbicide. Beets and Netherland (2018) evaluated florpyrauxifen-benzyl at similar concentrations (12 to $48 \mu \mathrm{g}$ a.i. $\mathrm{L}-$ 1) and exposure times (24-72 hr) against hydrilla and suggested longer exposures of 96-168 could be warranted to achieve control, especially at lower concentrations. In the current research, hydrilla control increased when herbicide concentrations were 24 or $36 \mu$ a.i. $\mathrm{L}^{-1}$ for $\geq 24 \mathrm{hr}$ exposures; therefore, higher florpyrauxifen-benzyl concentrations can decrease herbicide exposure time requirements for hydrilla. These results suggest that subsurface florpyrauxifen-benzyl applications during the spring can be efficacious against hydrilla if CET requirements are maintained; however, higher concentrations than those used in the current study may be needed to achieve complete control. 
Figure 2. Mean dry weight ( $\mathrm{g} \pm \mathrm{SE}$ ) response of hydrilla 8 WAT with subsurface applications of florpyrauxifen-benzyl in an outdoor mesocosm setting. Numbers behind herbicide concentrations ( $\mu$ g a.i. $\mathrm{L}^{-1}$ ) represent exposure time $(\mathrm{hr})$. Horizontal line represents pretreatment biomass. Treatments with the same letter are not significant according to Fisher's Protected LSD $(\alpha=0.05, n=4)$.

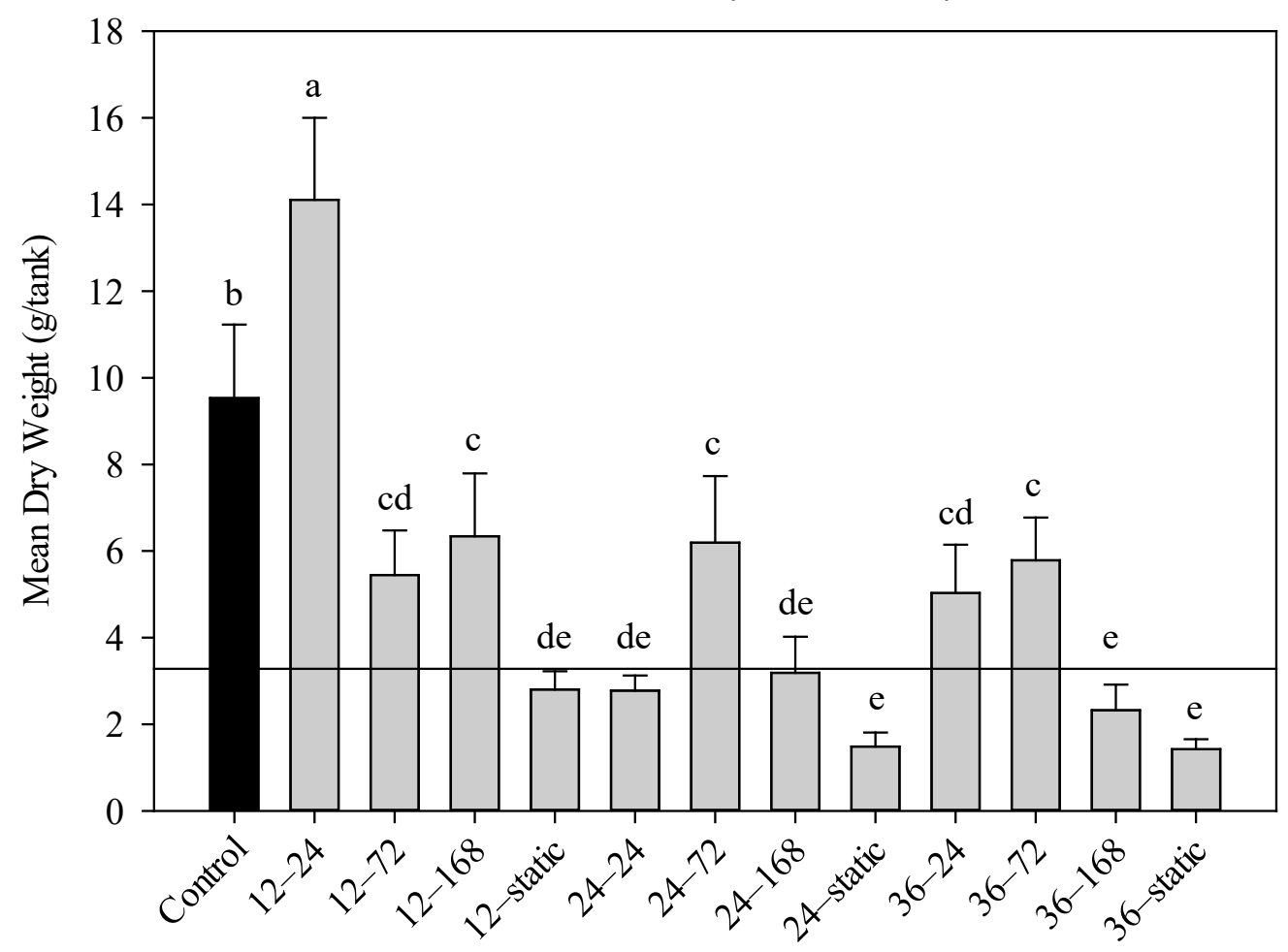

Herbicide Treatments

\subsection{Hybrid Watermilfoil Trial 1}

Hybrid watermilfoil exposed to $3-9 \mu$ g a.i. $\mathrm{L}^{-1}$ florpyrauxifen-benzyl for $\geq 3$ hr was injured within a few hours after application. Rapid injury symptoms included epinasty (twisting), swollen nodes, and chlorosis within the first 3 DAT. These early injury symptoms are consistent with those observed after field applications of florpyrauxifen-benzyl in lakes in Washington and Idaho (data not shown). This condition was followed by necrosis at 10-14 DAT. According to visual observations, very slight differences in injury symptoms occurred among CETs.

At 4 WAT, all CET treatments resulted in $98-100 \%$ control of hybrid watermilfoil with no differences among treatments (Figure 3). Only the following treatments had viable shoot tissue at the conclusion of the trial: 3 (12 hr exposure); 6 (6 hr); and $9 \mu \mathrm{g}$ a.i. $\mathrm{L}^{-1}$ for $3 \mathrm{hr}$ exposure treatments. These results demonstrate hybrid watermilfoil is highly susceptible to low concentrations of florpyrauxifen-benzyl ( $\leq 12 \mu \mathrm{g}$ a.i. $\left.\mathrm{L}^{-1}\right)$ for exposure 
periods of 3-24 hr. Previous research by Beets, Heilman, and Netherland (2019) investigated similar CET treatments and found florpyrauxifen-benzyl provided almost complete control of Eurasian and hybrid watermilfoil.

Figure 3. Mean dry weight ( $g \pm S E$ ) response of hybrid watermilfoil 8 WAT with subsurface applications of florpyrauxifen-benzyl in an outdoor mesocosm setting. Numbers behind herbicide concentrations ( $\mu \mathrm{g}$ a.i. $\mathrm{L}^{-1}$ ) represent exposure time (hr). Horizontal line represents pretreatment biomass. Treatments with the same letter are not significant according to Fisher's Protected LSD $(\alpha=0.05, n=4)$.

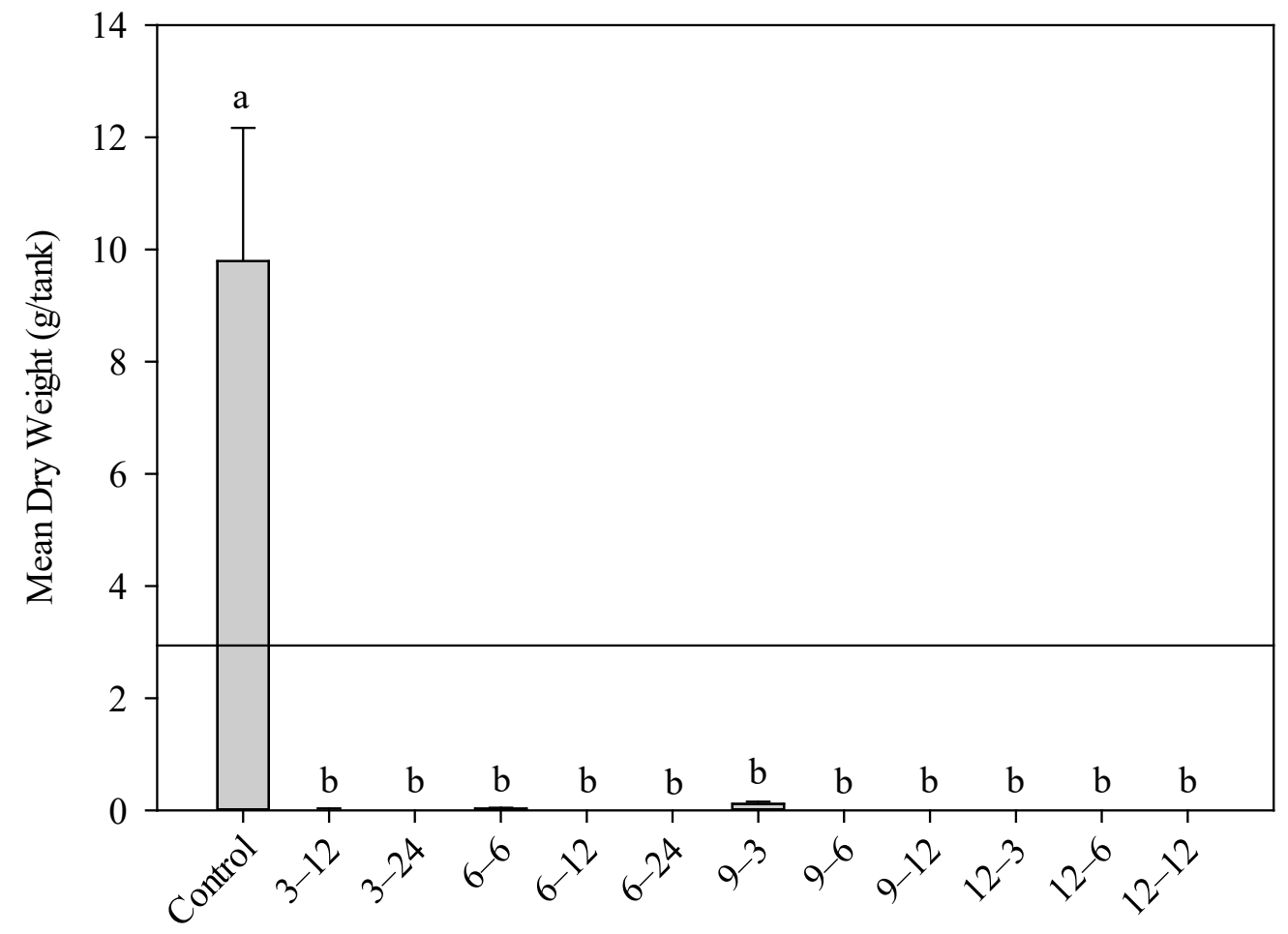

Herbicide Treatments

\subsection{Hybrid Watermilfoil and Non-Target Species Trial}

Since $>98 \%$ control was achieved by all florpyrauxifen-benzyl treatments in the initial trial, the follow-up trial examined lower herbicide concentrations and shorter exposure periods. The onset of injury symptoms exhibited by hybrid watermilfoil in the second growth chamber trial were identical to the previous trial; however, plant control was considerably slower in the second trial. At 5 WAT, all florpyrauxifen-benzyl treatments resulted in 50-100\% hybrid watermilfoil control and were significant in comparison to the nontreated control (Table 1). The $3 \mu \mathrm{g}$ a.i. $\mathrm{L}^{-1}$ at the $0.5 \mathrm{hr}$ exposure treatment provided 50\% control-significantly less than the $3(4 \mathrm{hr}$ exposure); 6 (all exposure times); and $9 \mu \mathrm{g}$ a.i. $\mathrm{L}^{-1}$ (all exposure times) treatments that provided $\geq 95 \%$ control. Similar to the initial hybrid 
watermilfoil trial, increased herbicide concentrations and exposure periods provided increased plant control, with half the CET treatments providing $100 \%$ plant control. In addition, plants showed rapid injury at all concentrations and exposures tested, thus indicating florpyrauxifen-benzyl's efficacy at short exposure times.

Table 1. Mean dry weight ( $g \pm S E$ ) response of hybrid watermilfoil, elodea, and water stargrass 8 WAT with subsurface applications of florpyrauxifen-benzyl in a growth chamber setting.

\begin{tabular}{lcll}
\hline Treatment & Hybrid Watermilfoil & Elodea & Water Stargrass \\
\hline Control & $1.90 \pm 0.28 \mathrm{ac}$ & $3.17 \pm 1.08$ & $1.40 \pm 0.56$ \\
$3-0.5$ & $0.95 \pm 0.57 \mathrm{~b}$ & $2.02 \pm 0.29$ & $1.64 \pm 0.44$ \\
$3-1$ & $0.31 \pm 0.22 \mathrm{~b}, \mathrm{c}$ & $1.81 \pm 0.94$ & $0.66 \pm 0.04$ \\
$3-2$ & $0.38 \pm 0.33 \mathrm{~b}, \mathrm{c}$ & $1.97 \pm 0.48$ & $1.06 \pm 0.47$ \\
$3-4$ & $0.00 \pm 0.00 \mathrm{c}$ & $2.12 \pm 0.14$ & $0.49 \pm 0.17$ \\
$6-0.5$ & $0.09 \pm 0.06 \mathrm{c}$ & $2.48 \pm 1.29$ & $1.33 \pm 0.51$ \\
$6-1$ & $0.02 \pm 0.01 \mathrm{c}$ & $1.43 \pm 0.74$ & $0.91 \pm 0.45$ \\
$6-2$ & $0.00 \pm 0.00 \mathrm{c}$ & $2.03 \pm 1.00$ & $0.43 \pm 0.08$ \\
$6-4$ & $0.00 \pm 0.00 \mathrm{c}$ & $1.02 \pm 0.19$ & $0.18 \pm 0.04$ \\
$9-0.5$ & $0.02 \pm 0.02 \mathrm{c}$ & $2.69 \pm 0.48$ & $0.50 \pm 0.15$ \\
$9-1$ & $0.00 \pm 0.00 \mathrm{c}$ & $0.87 \pm 0.31$ & $0.48 \pm 0.13$ \\
\hline
\end{tabular}

a Florpyrauxifen-benzyl treatments are expressed as concentration ( $\mu \mathrm{g}$ a.i. $\mathrm{L}^{-1}$ )-exposure time (hr).

b Pretreatment weights for hybrid watermilfoil, elodea, and water stargrass were $1.13 \pm 0.31$, $0.63 \pm 0.06$, and $0.31 \pm 0.11 \mathrm{~g}$, respectively.

c Means within a column followed by the same letter are not significantly different according to Fisher's Protected LSD at $\alpha=0.05 ; n=4$.

Elodea and water stargrass showed relative tolerance to subsurface applications of florpyrauxifen-benzyl, with no significant reductions in dry weight 5 WAT (Table 1). Observations from ongoing field trials in Washington and Idaho indicate tolerance of elodea and water stargrass (data not shown). Injury symptoms were less pronounced on the two native species; however, epinasty was observed in the tips of the water stargrass plants throughout the first 2 WAT, and a minimal amount of chlorosis was present, indicating that some level of herbicide activity was occurring. Elodea demonstrated a greater tolerance to florpyrauxifen-benzyl than water stargrass, and no injury symptoms were documented for elodea throughout the duration of the trial. Netherland and Richardson (2016) 
demonstrated $\mathrm{EC}_{50} \mathrm{O}$ values of $\leq 13.1 \mu \mathrm{g}$ a.i. $\mathrm{L}^{-1}$ for elodea when exposed to the original formulations of florpyrauxifen-benzyl being developed (SX1552 and SX-1552A) under continuous exposure for 14 days in small-scale growth chamber trials, which aligns with the results of this trial. In addition, elodea showed tolerance to all florpyrauxifen-benzyl concentrations and exposure periods when cultured under outdoor mesocosm conditions (Beets, Heilman, and Netherland 2019).

2,4-D and triclopyr are widely used auxin herbicides to control invasive watermilfoils species in the northern United States (Getsinger, Davis, and Brinson 1982; Getsinger et al. 1997; Poovey, Skogerboe, and Getsinger 2004; Poovey, Slade, and Netherland 2007) and can cause limited injury to elodea and water stargrass (Getsinger et al. 1997; Washington State Department of Ecology 2001; Poovey, Skogerboe, and Getsinger 2004; Wisconsin Department of Natural Resources 2012). However, these auxins have CET requirements (Green and Westerdahl 1990; Netherland and Getsinger 1992; Poovey, Skogerboe, and Getsinger 2004; Poovey, Slade, and Netherland 2007) that can limit their effectiveness in spot-treatment applications and plant stands growing in flowing water situations. On the basis of the limited negative impacts of florpyrauxifen-benzyl towards elodea and water stargrass at low use rates and short exposure periods used in the current hybrid watermilfoil trial, and previous Eurasian watermilfoil research (Netherland and Richardson 2016), this new herbicide could prove a useful tool to selectively manage target species in mixed nontarget populations. 


\section{Conclusions}

Although efficacy and selectivity were provided by florpyrauxifen-benzyl, longer exposures (several days or more) or concentrations $\geq 36 \mu \mathrm{g}$ a.i. $\mathrm{L}^{-1}$ or both may be required to provide optimal control of hydrilla when treating high levels of established biomass or treating under less favorable environmental conditions, including high water $\mathrm{pH}$, high water temperature, and high bulk water exchange. Conversely, excellent hybrid watermilfoil control can be achieved on young plants with florpyrauxifenbenzyl at $3 \mu \mathrm{g}$ a.i. $\mathrm{L}^{-1}$ if herbicide exposure is maintained for at least $4 \mathrm{hr}$. In scenarios where exposure time is limited to less than $4 \mathrm{hr}$, higher doses (for example, $6 \mu \mathrm{g}$ a.i. $\mathrm{L}^{-1}$ ) can provide excellent control if herbicide concentrations are maintained for $\geq 0.5 \mathrm{hr}$. Future work should evaluate florpyrauxifen-benzyl on other important native nontarget submersed plants and on different maturity levels of target plants. Finally, in order to fully understand the operational potential of florpyrauxifen-benzyl, field trials must be conducted to verify results of the studies reported here and efforts elsewhere (Beets and Netherland 2018; Beets, Heilman, and Netherland 2019). 


\section{References}

Beets, J., and M. Netherland. 2018. "Mesocosm response of crested floating heart, hydrilla, and two native emergent plants to florpyrauxifen-benzyl: A new arylpicolinate herbicide." J. Aquat. Plant Manage, 56:57-62.

Beets, J., M. Heilman, and M. D. Netherland. 2019. “Large-scale mesocosm evaluation of florpyrauxifen-benzyl, a novel arylpicolinate herbicide, on Eurasian and hybrid water milfoil and seven native submersed plants." J. Aquat. Plant Manage, 57:49-55.

Berger S. T., M. D. Netherland, and G. E. MacDonald. 2012. "Evaluating fluridone sensitivity of multiple hybrid and Eurasian water- milfoil accessions under mesocosm conditions.” J. Aquat. Plant Manag, 50:135-144.

Berger, S. T., M. D. Netherland, and G. E. MacDonald. 2015. "Laboratory documentation of multiple-herbicide tolerance to fluridone, norflurazon, and topramazone in a hybrid water milfoil (Myriophyllum spicatum x M. sibiricum) population." Weed Sci., 63:235-241.

Cook, C. D. K. 1985. "Range extensions of aquatic vascular plant species." J. Aquat. Plant Manage, 30:15-20.

DOW AgroSciences. 2017. Loyant herbicide label. https://s3-us-west-1.amazonaws.com/agriancg-fs1-production/pdfs/Loyant_Label.pdf.

Enloe, S. F., M. D. Netherland, W. Haller, and K. Langeland. 2018. Efficacy of herbicide active ingredients against aquatic weeds. University of Florida, Institute of Food and Agricultural Sciences. SS-AGR-44. https://edis.ifas.ufl.edu/ag262.

Getsinger, K. D., G. J. Davis, and M. M. Brinson. 1982. "Changes in a Myriophyllum spicatum L. community following a 2,4-D treatment.” J. Aquat. Plant Manage. 20:4-8.

Getsinger, K., and C. Mudge. 2018. Selective Control of Submersed Invasive Plants with a New Arylpicolinate Herbicide. https://corpslakes.erdc.dren.mil/employees/learning/webinars/18Apr25ProcellacorAPCRP.pdf.

Getsinger, K. D., and M. D. Netherland. 1997. "Herbicide concentration/exposure time requirements for controlling submersed aquatic plants: Summary of research accomplishments.” Miscellaneous Paper A-97-2. Vicksburg, MS: US Army Engineer Waterways Experiment Station.

Getsinger, K. D., E. G. Turner, J. D. Madsen, and M. D. Netherland. 1997. “Restoring native plant vegetation in a Eurasian water milfoil-dominated plant community using the herbicide triclopyr." Reg. Rivers Res. Manage, 13:357-375.

Glomski, L. M., and M. D. Netherland. 2010. "Response of Eurasian and hybrid water milfoil to low use rates and extended exposures of 2,4-D and triclopyr." J Aquat. Plant Manage, 48:12-14. 
Green, W. R., and H. E. Westerdahl. 1990. "Response of Eurasian water milfoil to 2,4-D concentrations and exposure times." J. Aquat. Plant Manage, 28:27-32.

Haller, W. T., and D. L. Sutton. 1975. "Community structure and competition between hydrilla and vallisneria." Hyacinth Contr. J. 13:48-50.

Langeland K. A. 1996. Hydrilla verticillata (L.F.) Royle (Hydrocharitaceae), "The Perfect Aquatic Weed". Castanea 61:293-304. https://www.jstor.org/stable/4033682.

LaRue, E. A, M. P. Zuellig, M. D. Netherland, M. A. Heilman, and R. A. Thum. 2013. "Hybrid water milfoil lineages are more invasive and less sensitive to a commonly used herbicide than their exotic parent (Eurasian water milfoil)." Evol. Appl. 6:462-71.

LSU AgCenter. 2017. Louisiana Agriclimatic Information System. (Accessed on 13 June 2019). http://weather.Isuagcenter.com/Default.aspx.

Moody, M. L., and D. H. Les. 2002. "Evidence of hybridity in invasive water milfoil (Myriophyllum) populations.” Proc. Natl. Acad. Sci. 99:14867-14871.

Moody, M. L., and D. H. Les. 2007. "Geographic distribution and genotypic composition of invasive hybrid water milfoil (Myriophyllum spicatum $\times$ M. sibiricum).” Biol. Invasions, 9:559-570.

Mudge, C. R., and H. J. Theel. 2011. "Endothall concentration exposure time evaluation against Eurasian watermilfoil at a lower water temperature. APCRP Technical Note Collections.” ERDC/TN APCRP-CC-15. Vicksburg, MS: U.S. Army Engineer Research and Development Center, Vicksburg, MS.

Netherland, M. D. 2014. Chemical control of aquatic weeds. In Biology and Control of Aquatic Plants: A Best Management Practices Handbook. $3^{\text {rd }}$ ed. Marietta, GA: Aquatic Ecosystem Restoration Foundation.

Netherland, M. D., and K. D. Getsinger. 1992. "Efficacy of triclopyr on Eurasian water milfoil: Concentration and exposure time effects.” J. Aquat. Plant Manage, 30:15 .

Netherland, M. D, and K. D. Getsinger. 2018. "Scaling studies for submersed aquatic plant management research.” J. Aquat. Plant Manag., 56s:10-16.

Netherland, M. D., W. R. Green, and K. D. Getsinger. 1991. "Endothall concentration and exposure time relationships for the control of Eurasian water milfoil and hydrilla." J. Aquat. Plant Manage, 29:61-67.

Netherland, M. D., and K. D. Jones. 2012. "Registered herbicides and improving their efficacy on aquatic weeds." Aquatics, 34(3):12-15.

Netherland, M. D., and R. J. Richardson. 2016. "Evaluating sensitivity of five aquatic plants to a novel arylpicolinate herbicide utilizing an organization for economic cooperation and development protocol." Weed Sci., 64:181-190. 
Poovey, A. G., J. G. Skogerboe, and K. D. Getsinger. 2004. “Efficacy of AVAST! ${ }^{\circledR}$ Fluridone Formulation Against Eurasian Water milfoil and Nontarget Submersed Plants.” ERDC/EL TR-04-9. Vicksburg, MS: U. S. Army Engineer Research and Development Center.

Poovey, A. G., J. G. Slade, and M. D. Netherland. 2007. "Susceptibility of Eurasian water milfoil (Myriophyllum spicatum) and a milfoil hybrid (M. spicatum $\times M$. sibiricum) to triclopyr and 2,4-D amine." J. Aquat. Plant Manage, 45:111-115.

Richardson, R. J., E. J. Haug, and M. D. Netherland. 2016. "Response of seven aquatic plants to a new arylpicolinate herbicide." J. Aquat. Plant Manage, 54:26-31.

Smart, R. M., and J. W. Barko. 1985. "Laboratory culture of submersed freshwater macrophytes on natural sediments." Aquatic Botany, 21:251-263.

Thum, R. A., M. A. Heilman, P. J. Hausier, L. E. Huberty, P. Tyning, D. J. Weisel, M. P. Zuellig, S. T. Berger, and M. D. Netherland. 2012. "Field and laboratory documentation of reduced fluridone sensitivity of a hybrid water milfoil biotype (Myriophyllum spicatum X Myriophyllum sibiricum).” J. Aquat. Plant Manage, 50:141-146.

University of Florida. 2018. Plant management in Florida waters: an integrated approach. Details about the aquatic herbicides used in Florida. Gainesville, FL: University of Florida. (Accessed on 16 June 2019). http://plants.ifas.ufl.edu/manage/controlmethods/details-about-the-aquatic-herbicides-used-in-florida.

[USDA] United States Department of Agriculture. 2019. https://plants.sc.egov.usda.gov/java/.

United States Environmental Protection Agency (USEPA). 2017. Registration review process. (Accessed on 16 June 2019). https://www.epa.gov/pesticidereevaluation/registration-review-process.

Van, T. K., and V. V. Vandiver. 1992. "Response of monoecious and dioecious hydrilla to bensulfuron methyl.” J. Aquat. Plant Manage, 30:41-44.

Washington State Department of Ecology. 2001. Herbicide risk assessment for the aquatic plant management final supplemental environmental impact statement. Appendix C Volume 3: 2,4-D. https://fortress.wa.gov/ecy/publications/ documents/0010043.pdf.

Weimer, M. R., C. N. Yerkes, P.R. Schmitzer, and P. K. Mann. 2015. Introduction to a new arylpicolinate herbicide from DOW AgroSciences with utility in rice and other crops. Weed Science Society of America Abstracts. 55.

Wisconsin Department of Natural Resources. 2012. 2,4-D chemical fact sheet. DNR PUBWT-964. https://dnr.wi.gov/lakes/plants/factsheets/2,4-DFactSheet.pdf. 


\section{Acronyms and Abbreviations}

\begin{tabular}{|l|l|}
\hline \multicolumn{1}{|c|}{ Acronym } & \multicolumn{1}{c|}{ Meaning } \\
\hline AARF & AgCenter Aquaculture Research Facility \\
\hline APCRP & Aquatic Plant Control Research Program \\
\hline DAT & days after treatment \\
\hline EL & Environmental Laboratory \\
\hline ERDC & Engineer Research and Development Center \\
\hline LSU & Louisiana State University \\
\hline USACE & US Army Corps of Engineers \\
\hline USEPA & US Environmental Protection Agency \\
\hline WAT & weeks after treatment \\
\hline
\end{tabular}




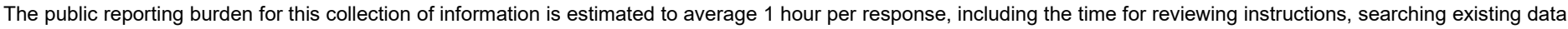

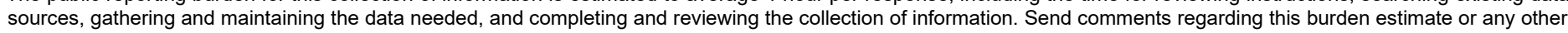

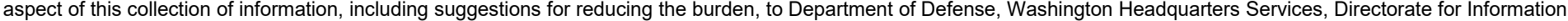

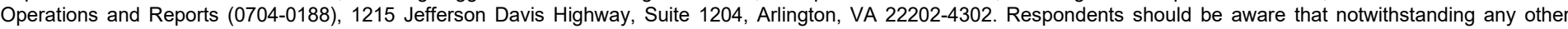

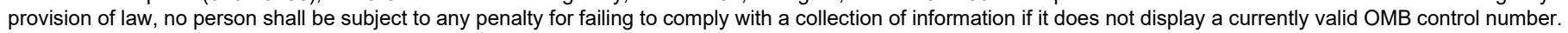
PLEASE DO NOT RETURN YOUR FORM TO THE ABOVE ADDRESS.

\section{\begin{tabular}{l|l} 
1. REPORT DATE & 2. REPORT TYPE
\end{tabular} \\ September 2021 \\ Final Technical Report}

4. TITLE AND SUBTITLE

Efficacy of Florpyrauxifen-benzyl on Dioecious Hydrilla and Hybrid Water Milfoil -

Concentration and Exposure Time Requirements

6. $\operatorname{AUTHOR(S)}$

Christopher R. Mudge, Bradley T. Sartain, Kurt D. Getsinger, and Michael. D. Netherland

\section{PERFORMING ORGANIZATION NAME(S) AND ADDRESS(ES)}

U.S Army Engineer Research and Development Center

Environmental Laboratory

3909 Halls Ferry Road, Vicksburg, MS 39180-6199

\section{SPONSORING/MONITORING AGENCY NAME(S) AND ADDRESS(ES)}

Headquarters, US Army Corps of Engineers

Washington, DC 20314-1000
3. DATES COVERED (From - To)

5a. CONTRACT NUMBER

5b. GRANT NUMBER

5c. PROGRAM ELEMENT NUMBER

5d. PROJECT NUMBER

5e. TASK NUMBER

5f. WORK UNIT NUMBER

8. PERFORMING ORGANIZATION REPORT NUMBER

ERDC/EL TR-21-8

10. SPONSOR/MONITOR'S ACRONYM(S)

HQUSACE

11. SPONSOR/MONITOR'S REPORT NUMBER(S)

\section{DISTRIBUTION/AVAILABILITY STATEMENT}

Approved for public release; distribution is unlimited.

\section{SUPPLEMENTARY NOTES}

AMSCO for this work is 075098 ; the funding account is U4359660.

\section{ABSTRACT}

This study conducted small-scale trials under various concentration and exposure time (CET) scenarios to determine florpyrauxifenbenzyl activity on dioecious hydrilla and hybrid watermilfoil and determine impact on water stargrass and elodea. Hydrilla treated with 12,24 , or $36 \mu$ g active ingredient (a.i.) $\mathrm{L}^{-1}$ florpyrauxifen-benzyl and exposed for 12 , 24, or $48 \mathrm{hr}$ under outdoor mesocosm conditions was reduced in biomass by $30-75 \%$ at 8 weeks after treatment (WAT). An additional hydrilla trial at the same herbicide concentrations, but under longer exposures $(24,72$, or $168 \mathrm{hr})$, resulted in $33-85 \%$ plant control. Under indoor conditions, hybrid watermilfoil dry weight decreased 98-100\% with subsurface applications of florpyrauxifen-benzyl under CET scenarios of 3-12 $\mu$ g a.i. L ${ }^{-1}$ at 3-24 hr exposure times in a growth chamber trial. Under shorter exposure periods $(0.5-4 \mathrm{hr})$ in a follow-up trial, low doses $\left(3-9 \mu \mathrm{g}\right.$ a.i. $\left.\mathrm{L}^{-1}\right)$ achieved $50-$ $100 \%$ control of hybrid watermilfoil. In the same trial, the nontarget species water stargrass and elodea proved relatively tolerant to the florpyrauxifen-benzyl at doses up to $6 \mu \mathrm{g}$ a.i. $\mathrm{L}^{-1}$ ( $4 \mathrm{hr}$ exposure) and $9 \mu \mathrm{g}$ a.i. $\mathrm{L}^{-1}$ ( $1 \mathrm{hr}$ exposure). These small-scale trials demonstrate florpyrauxifen-benzyl's potential to selectively manage invasive species.

\section{SUBJECT TERMS}

Aquatic herbicides Aquatic plants Eurasian watermilfoil Hydrilla

\begin{tabular}{|c|c|c|c|}
\hline \multicolumn{3}{|c|}{ 16. SECURITY CLASSIFICATION OF: } & \multirow{2}{*}{$\begin{array}{l}\text { 17. LIMITATION OF } \\
\text { ABSTRACT } \\
\text { SAR }\end{array}$} \\
\hline $\begin{array}{l}\text { a. } \\
\text { REPORT } \\
\text { Unlimited }\end{array}$ & $\begin{array}{l}\text { b. ABSTRACT } \\
\text { Unlimited }\end{array}$ & $\begin{array}{l}\text { c. THIS PAGE } \\
\text { Unlimited }\end{array}$ & \\
\hline
\end{tabular}
\begin{tabular}{l|l} 
18. NUMBER & 19a. NAME OF RESPONSIBLE PERSON
\end{tabular} OF PAGES

